\title{
Temperature response of denitrification and anammox reveals the adaptation of microbial communities to in situ temperatures in permeable marine sediments that span $50^{\circ}$ in latitude
}

\author{
A. Canion ${ }^{1, *}$, J. E. Kostka ${ }^{1, * *}$, T. M. Gihring ${ }^{1}$, M. Huettel ${ }^{1}$, J. E. E. van Beusekom ${ }^{2, * * *}$, H. Gao ${ }^{3, * * * *}$, G. Lavik ${ }^{3}$, and \\ M. M. M. Kuypers ${ }^{3}$ \\ ${ }^{1}$ Earth, Ocean, and Atmos. Science Dept, Florida State University, Tallahassee, Florida, USA \\ ${ }^{2}$ Alfred Wegener Institute for Polar and Marine Research, List, Germany \\ ${ }^{3}$ Max Planck Institute for Marine Microbiology, Bremen, Germany \\ * now at: St. Johns River Water Management District, Palatka, Florida, USA \\ ** now at: Schools of Biology and Earth and Atmospheric Science, Georgia Institute of Technology, Atlanta, Georgia, USA \\ *** now at: Institute of Coastal Research, Helmholtz Zentrum Geesthacht, Geesthacht, Germany \\ **** now at: School of Ocean and Earth Sciences, Tonji University, Shanghai, China
}

Correspondence to: J. E. Kostka (joel.kostka@biology.gatech.edu)

Received: 22 August 2013 - Published in Biogeosciences Discuss.: 3 September 2013

Revised: 26 November 2013 - Accepted: 4 December 2013 - Published: 23 January 2014

\begin{abstract}
Despite decades of research on the physiology and biochemistry of nitrate/nitrite-respiring microorganisms, little is known regarding their metabolic response to temperature, especially under in situ conditions. The temperature regulation of microbial communities that mediate anammox and denitrification was investigated in near shore permeable sediments at polar, temperate, and subtropical sites with annual mean temperatures ranging from -5 to $23^{\circ} \mathrm{C}$. Total $\mathrm{N}_{2}$ production rates were determined using the isotope pairing technique in intact core incubations under diffusive and simulated advection conditions and ranged from 2 to $359 \mu \mathrm{mol} \mathrm{N} \mathrm{m}{ }^{-2} \mathrm{~d}^{-1}$. For the majority of sites studied, $\mathrm{N}_{2}$ removal was 2-7 times more rapid under simulated advective flow conditions. Anammox comprised 6-14\% of total $\mathrm{N}_{2}$ production at temperate and polar sites and was not detected at the subtropical site. Potential rates of denitrification and anammox were determined in anaerobic slurries in a temperature gradient block incubator across a temperature range of $-1{ }^{\circ} \mathrm{C}$ to $42^{\circ} \mathrm{C}$. The highest optimum temperature $\left(T_{\text {opt }}\right)$ for denitrification was $36^{\circ} \mathrm{C}$ and was observed in subtropical sediments, while the lowest $T_{\text {opt }}$ of $21^{\circ} \mathrm{C}$ was observed at the polar site. Seasonal variation in the $T_{\mathrm{opt}}$ was observed at the temperate site with values of 26 and $34{ }^{\circ} \mathrm{C}$ in winter and summer, respectively. The $T_{\text {opt }}$ values for anammox were 9 and
\end{abstract}

$26^{\circ} \mathrm{C}$ at the polar and temperate sites, respectively. The results demonstrate adaptation of denitrifying communities to in situ temperatures in permeable marine sediments across a wide range of temperatures, whereas marine anammox bacteria may be predominately psychrophilic to psychrotolerant. The adaptation of microbial communities to in situ temperatures suggests that the relationship between temperature and rates of $\mathrm{N}$ removal is highly dependent on community structure.

\section{Introduction}

Denitrification and anammox are the dominant processes for nitrogen loss in the ocean. These microbially mediated reactions convert dissolved inorganic nitrogen to $\mathrm{N}_{2}$ and are limited to suboxic and anoxic regions of the ocean, including oxygen minimum zones and surficial sediments (Thamdrup and Dalsgaard, 2008). A large portion of nitrogen removal occurs in coastal sediments, where high primary productivity and export production provide abundant organic matter and dissolved inorganic nitrogen that fuels denitrification and anammox. Current nitrogen budgets attribute up to $50 \%$ of the global ocean nitrogen loss to near shore coastal 
and continental shelf sediments (Codispoti, 2007). Continental shelves are dominated (up to $70 \%$ ) by relatively coarsegrained, relict sediments (Emery, 1968); however, the contribution of these permeable continental shelf sediments to nitrogen removal remains poorly constrained (Galloway et al., 2004).

Recent field experiments and modeling efforts have demonstrated the central role of pore water advection in controlling rates of $\mathrm{N}$ removal in sandy permeable sediments (Huettel et al., 2014). The transport of solutes and particles by pressure-gradient-driven pore water advection enhances mineralization processes in permeable sediments by delivering dissolved and particulate substrates and removing metabolic end products (Huettel and Rusch, 2000). Pore water advection supplies nitrate from the overlying water and may enhance coupled nitrification-denitrification as a result of an expanded oxic zone. Enhancement of denitrification by pore water advection has been shown to be highly influenced by the rate of pore water flushing and sediment topography. Denitrification rates generally increase with pore water flushing rate, but under high flushing rates or in highly permeable sands, the extent of anoxic zones may limit denitrification (Cardenas et al., 2008; Cook et al., 2006). Sediment topography may limit coupled nitrification-denitrification due to preferential flow of ammonium-rich water through anaerobic zones at ripple crests (Kessler et al., 2012). However, nitrification has been shown in some cases to be tightly coupled to denitrification at high flushing rates in sand under continuous advection (Gihring et al., 2010), indicating that zones of nitrification and ammonium production can be tightly coupled.

To parameterize large-scale models of nitrogen removal from continental shelves, the response of denitrification and anammox to environmental controls must be quantified. Major environmental controls of denitrification and anammox activity have been extensively studied in fine-grained sediments and include, but are not limited to, the availability of organic matter, nitrate concentration in the overlying water, $\mathrm{O}_{2}$ penetration depth, and the extent of bioturbation (Cornwell et al., 1999). Temperature is often considered a master variable because it exerts a modulating effect on multiple physical and biogeochemical processes. The effect of temperature on microbial communities mediating denitrification is limited to a few studies. In previous studies from salt-marsh sediments, seasonal variation in the temperature response of denitrification rates showed that communities with lower optimal temperatures for denitrification became active during winter months (Kaplan et al., 1977; King and Nedwell, 1984). Ogilvie et al. (1997) demonstrated that lower temperatures led to the enrichment of denitrifying isolates, whereas higher temperatures enriched for bacteria that performed dissimilatory nitrate reduction to ammonium, demonstrating that temperature may have an effect on the dominant nitrate reduction pathway. Denitrification and anammox in Arctic fjord muds were shown to have optimal temperatures of 25 and $12{ }^{\circ} \mathrm{C}$, respectively, indicating that the anammox bacteria were better adapted to cold conditions (Rysgaard et al., 2004). Together, these studies illustrate that the response of nitrogen removal pathways to the in situ temperature may be strongly dependent on the community structure.

Despite decades of research on the physiology and biochemistry of nitrate-respiring microorganisms, little is known regarding their metabolic response to temperature, especially under in situ conditions. In the present study, we examined the temperature adaptation of denitrifying and anammox communities in near-shore, permeable sediments spanning a $50^{\circ}$ latitudinal range. Permeable sediments were chosen because they dominate continental shelf sediments and may be important sites for nitrogen removal. We hypothesized that the temperature response of denitrification and anammox will vary according to the in situ temperature of the sediment. To this end, rate measurements employing the isotope pairing technique $\left({ }^{15} \mathrm{~N}\right.$ tracer) and temperature gradient block incubations were performed with permeable sediments from subtropical (northeastern Gulf of Mexico), temperate (German Wadden Sea), and Arctic (Svalbard, Norway) sites with annual mean temperatures of 23,11 , and $-5^{\circ} \mathrm{C}$, respectively. The results demonstrate adaptation of denitrifying communities to in situ temperatures and suggest that marine anammox bacteria are psychrophilic to psychrotolerant.

\section{Methods}

\subsection{Study sites}

Near shore, permeable sediments were sampled at a total of 4 sites from subtropical, temperate and polar temperature regimes (Fig. 1, Table 1). The two subtropical sites were located at St. George Island (SGI), Florida $\left(29.7^{\circ} \mathrm{N}\right)$, which is a barrier island in the northeastern Gulf of Mexico. The annual mean water temperature at SGI is $23^{\circ} \mathrm{C}$ (N.D.B.C. , Station SGOF1), and samples were taken in June 2010 from the subtidal zone located approximately $50 \mathrm{~m}$ from shore at $1.5 \mathrm{~m}$ depth. The temperate site was located at Hausstrand, the island of Sylt $\left(55.0^{\circ} \mathrm{N}\right)$, in the German Wadden Sea. The annual mean water temperature at Sylt in 2007 was $11.0^{\circ} \mathrm{C}$ and comparable to the long-term mean (1984-2007) of $10.5^{\circ} \mathrm{C}$ (Hedtkamp, 2005). Samples were taken on intertidal flats in March (mean temperature 5.6 ${ }^{\circ} \mathrm{C}$ ) and June 2007 (mean temperature $17.9^{\circ} \mathrm{C}$ ). Polar permeable sediments were sampled in August 2010 on an intertidal flat at Ymerbukta $\left(78.3^{\circ} \mathrm{N}\right)$ on the island of Spitsbergen (Svalbard). This region has an annual mean temperature of $-5^{\circ} \mathrm{C}$ (Forland and HanssenBauer, 2003), and sediments remain frozen from fall to spring (Sawicka et al., 2010). 


\subsection{Denitrification and anammox rates determined using intact cores}

At each site, $15 \mathrm{~cm}$-long sediment cores with $15 \mathrm{~cm}$ of overlying water were collected by hand using $3.5 \mathrm{~cm}-$ diameter core liners. Cores were immediately transported to temperature-controlled rooms and stored at the in situ temperature until incubation experiments were initiated (less than $24 \mathrm{~h}$ ). All incubations were maintained at the in situ temperature measured at the time of core collection. Denitrification and anammox rate determinations were performed using the ${ }^{15} \mathrm{~N}$ isotope pairing technique (IPT, Nielsen, 1992) with modification to account for anammox according to RisgaardPetersen et al. (2003). For each site and sample date, IPT experiments were performed in the dark with and without pore-water perfusion as described in de Beer et al. (2005). Overlying water was removed from the cores and replaced with air-equilibrated site water to which $50 \mu \mathrm{M} \mathrm{Na}^{15} \mathrm{NO}_{3}^{-}$ (99 atom \%; Cambridge Isotope Laboratories, Andover, MA) was added. One set of cores was immediately capped without headspace and submerged in water collected from the field site. A second set of cores was perfused with $20 \mathrm{~mL}$ of $\mathrm{Na}^{15} \mathrm{NO}_{3}^{-}$-amended site water by slowly pumping water with a syringe through a valve in the top stopper closing the core liners, while excess water was released through a valve in the bottom stopper of the core liners. The core diameter, sediment porosity, and volume of water perfused were used to calculate the depth of perfusion, which was approximately $5.0 \mathrm{~cm}$ for the subtropical and temperate sites and $7 \mathrm{~cm}$ for the polar site. Mixing of the water column in the cores was maintained by magnetic stir bars that were continuously rotated using an external magnet. Triplicate cores were sacrificed at each time point by the addition of $1 \mathrm{~mL}$ of $\mathrm{ZnCl}_{2}$ $(50 \% \mathrm{w} / \mathrm{v})$ to the water in the core liners, resealing the core without headspace, and inverting to homogeneously mixed sediment, $\mathrm{ZnCl}_{2}$, and water. Water samples were then collected by a syringe while avoiding the introduction of air bubbles and transferred to $12 \mathrm{~mL}$ Exetainer ${ }^{\circledR}$ vials containing $250 \mu \mathrm{L}$ of $50 \% \mathrm{ZnCl}_{2}$ added as a preservative. The total length and sampling interval of incubations was determined using preliminary data and was adjusted according to expected rates of $\mathrm{N}_{2}$ production. Incubations lengths were 18, 55, and $72 \mathrm{~h}$ for Sylt, Ymerbukta, and SGI, respectively.

Linear regressions of excess ${ }^{29} \mathrm{~N}_{2}$ or ${ }^{30} \mathrm{~N}_{2}$ concentration (see analytical procedures) against time were used to calculate the rates of ${ }^{29} \mathrm{~N}_{2}$ and ${ }^{30} \mathrm{~N}_{2}$ production. All regression slopes were determined to be significantly greater than 0 ( $t$ test, $p<0.05$ ), and the standard error of the regression slopes was used to calculate the error of denitrification and anammox rates. Volumetric calculations of denitrification and anammox were adjusted to areal rates using the sediment height, core diameter, and sediment porosity. At sites where anammox was negligible, the denitrification rate, $\mathrm{D}_{14}$, was calculated according to Nielsen (1992). Where anammox was detected, anaerobic slurry incubations were performed to determine the relative contribution of anammox to $\mathrm{N}_{2}$ production (ra), and rates were calculated according to Risgaard-Petersen et al. (2003). The slurries were performed by adding $1 \mathrm{~mL}$ of homogenized wet sediment from the surface $(0-5 \mathrm{~cm})$ to a $12 \mathrm{~mL}$ Exetainer ${ }^{\circledR}$, which was then filled without headspace with site water containing $100 \mu \mathrm{M} \mathrm{Na}^{15} \mathrm{NO}_{3}^{-}$. Vials were incubated for $24-48 \mathrm{~h}$ at the in situ temperature and sampled every $6 \mathrm{~h}$ in triplicate by addition of $250 \mu \mathrm{L}$ of $50 \% \mathrm{ZnCl}_{2}$. The calculations of Thamdrup and Dalsgaard (2002) were used to determine the contribution of anammox.

\subsection{Vertical profiles of denitrification and anammox}

Vertical profiles of the potential rates of denitrification and anammox were determined in the Sylt sediments in June 2007. Cores were sectioned at $2 \mathrm{~cm}$ intervals, and sediment was slurried with bottom water in sealed gasimpermeable bags. The bottom water was amended with $100 \mu \mathrm{M} \mathrm{Na}^{15} \mathrm{NO}_{3}^{-}$(99 atom \%), and the bags were flushed with helium to ensure anaerobic conditions. The slurries were incubated at the in situ temperature. Samples for the determination of ${ }^{29} \mathrm{~N}_{2}$ and ${ }^{30} \mathrm{~N}_{2}$ production were taken at 3,6 , 12 , and $20 \mathrm{~h}$ and preserved in $6 \mathrm{~mL}$ Exetainers ${ }^{\circledR}$ with $\mathrm{ZnCl}_{2}$ as described above. Potential denitrification and anammox were calculated according to the equations of Thamdrup and Dalsgaard (2002). Vertical profiles of pore-water nitrate, nitrite, and ammonium concentrations were measured at the time of core collection using Rhizon samplers (Rhizosphere Research Products) that were inserted into ports drilled at $1 \mathrm{~cm}$ intervals in polycarbonate core liners $(9.5 \mathrm{~cm}$ diameter $)$ (Seeberg-Elverfeldt et al., 2005). Rhizons were rinsed with the first $0.5 \mathrm{~mL}$ of extracted pore-water, and $2 \mathrm{~mL}$ were collected for each $1 \mathrm{~cm}$-depth interval for a total depth of $10 \mathrm{~cm}$.

\subsection{Temperature gradient block experiments}

The temperature response of potential denitrification and anammox rates was determined using temperature gradient block incubators (cf., Sagemann et al., 1998) located at either the Max Planck Institute for Marine Microbiology (Bremen, Germany) or Florida State University (Tallahassee, Florida). The two temperature blocks were identical in size: each consisted of a $2 \mathrm{~m}$-long (cross section $15 \mathrm{~cm} \times 15 \mathrm{~cm}$ ) insulated aluminum block that was electrically heated at one end and cooled at the other by a circulating water bath. Each block had 4 parallel rows of 30 vertical wells $(1.8 \mathrm{~cm}$ diameter, $15 \mathrm{~cm}$ length), with 3 rows for samples and one row for temperature monitoring.

At the time of intact core collection, samples for temperature gradient experiments were collected from the upper $5 \mathrm{~cm}$ of the sediments into pre-sterilized plastic containers and stored at the in situ temperature. Potential rates of denitrification and anammox were determined in time series incubations of anaerobic slurries across a temperature range of 

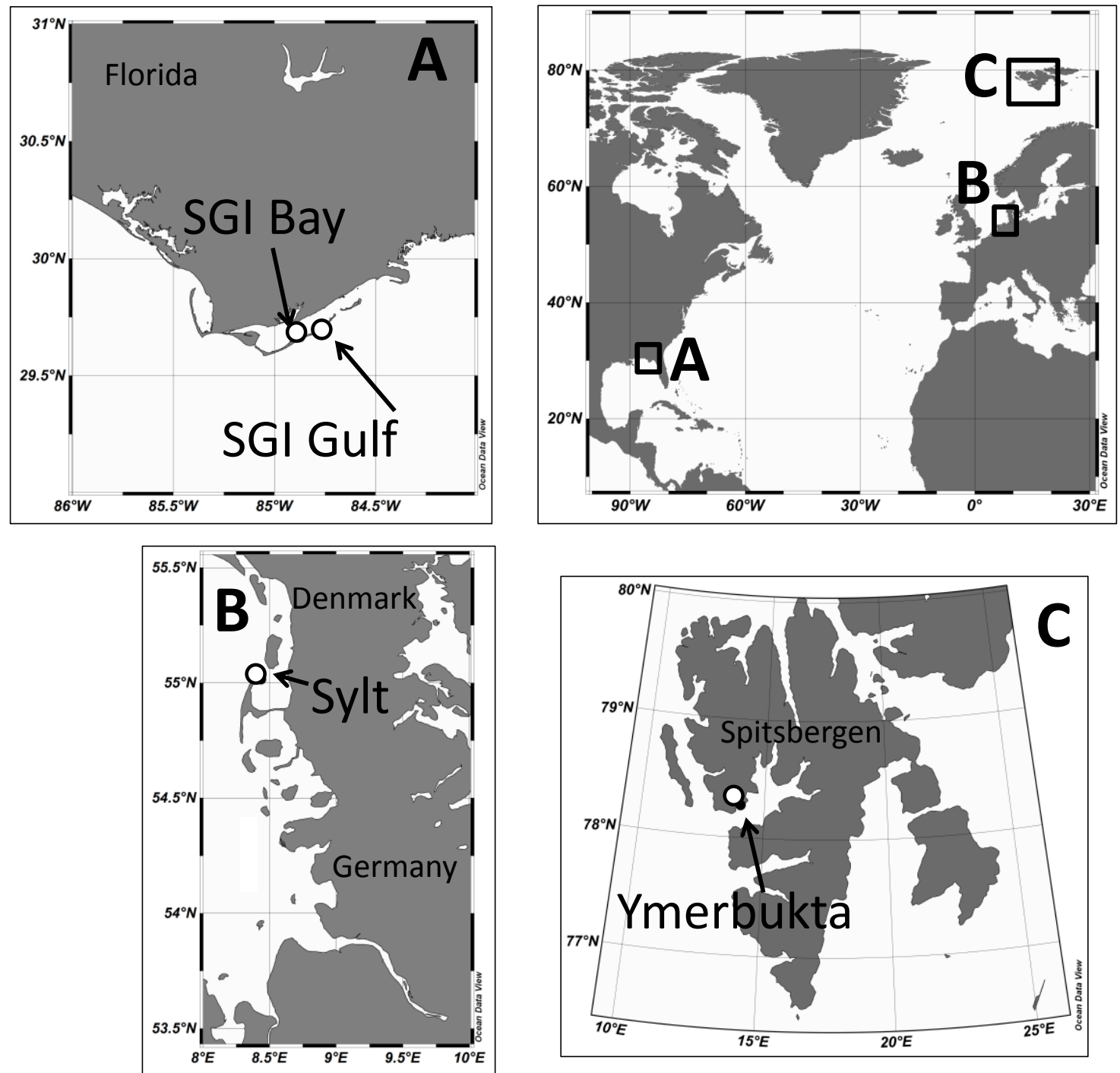

Fig. 1. Location of the sample sites.

Table 1. Sample site locations and sediment characteristics. Sites at Ymerbukta and Sylt were intertidal, and the sites at SGI were subtidal.

\begin{tabular}{|c|c|c|c|c|c|c|c|}
\hline Site & Coordinates & $\begin{array}{l}\text { Mean water } \\
\text { temperature } \\
\text { (range) }\end{array}$ & $\begin{array}{l}\text { Sediment } \\
\text { type }\end{array}$ & $\begin{array}{r}\text { Median } \\
\text { grain } \\
\text { size }(\mu \mathrm{M})\end{array}$ & $\begin{array}{r}\text { Permeability } \\
\qquad\left(\mathrm{m}^{2}\right)\end{array}$ & $\begin{array}{r}\text { Corg } \\
\text { (wt \%) }\end{array}$ & $\mathrm{C}: \mathrm{N}$ \\
\hline SGI Gulf (Gulf of Mexico) $)^{a}$ & $29^{\circ} 41.73^{\prime} \mathrm{N}, 84^{\circ} 46.25^{\prime} \mathrm{W}$ & $23^{\circ} \mathrm{C}(14$ to 33$)$ & Slightly gravelly fine sand & 223 & $2.4 \times 10^{-11}$ & 0.04 & 8.1 \\
\hline Sylt (Wadden Sea) ${ }^{\mathrm{b}}$ & $55^{\circ} 00.90^{\prime} \mathrm{N}, 08^{\circ} 26.20^{\prime} \mathrm{E}$ & $11^{\circ} \mathrm{C}(2$ to 19$)$ & Moderately well sorted medium sand & 338 & $4.8 \times 10^{-11}$ & 0.13 & 7.1 \\
\hline Ymerbukta $\left(\right.$ Svalbard) $^{\mathrm{c}}$ & $78^{\circ} 16.42^{\prime} \mathrm{N}, 14^{\circ} 01.96^{\prime} \mathrm{E}$ & $-5^{\circ} \mathrm{C}(-20$ to 9$)$ & Sandy very fine gravel & 824 & $1.0 \times 10^{-10}$ & 0.49 & 22.6 \\
\hline
\end{tabular}

${ }^{a}$ Grain size and permeability from Chipman et al. (2012), ${ }^{b}$ sediment characteristics from Hedtkamp (2005), ${ }^{c}$ permeability estimated for Ymerbukta site according to the Carman-Kozeny equation.

-1.0 to $42^{\circ} \mathrm{C}$. Slurries were prepared by adding $1 \mathrm{~mL}$ of wet sediment to a $12 \mathrm{~mL}$ Exetainer ${ }^{\circledR}$ vial followed by filling of the vials with helium-degassed site water that was amended with $\mathrm{Na}^{15} \mathrm{NO}_{3}$ to a final concentration of $100 \mu \mathrm{M}$. One set of samples was sacrificed at each time point by the addition of $250 \mu \mathrm{L}$ of $50 \% \mathrm{ZnCl}_{2}$ to each vial, followed by vigorous mixing. Four time points were sampled for each experiment over a period of 15-24 h. Parallel anaerobic slurries were incubated at the in situ temperature and sampled in triplicate at each time point to verify homogeneity between vials. The production of labeled $\mathrm{N}_{2}$ was calculated as described for the core incubations by the regression of ${ }^{29} \mathrm{~N}_{2}$ and ${ }^{30} \mathrm{~N}_{2}$ against 
time, and the calculations of Thamdrup and Dalsgaard (2002) were used to partition ${ }^{29} \mathrm{~N}_{2}$ and ${ }^{30} \mathrm{~N}_{2}$ production into potential denitrification and anammox rates.

An additional temperature block experiment was performed to determine anammox activity at each site, whereby production of ${ }^{29} \mathrm{~N}_{2}$ and the absence of ${ }^{30} \mathrm{~N}_{2}$ after addition of $100 \mu \mathrm{M}{ }^{15} \mathrm{NH}_{4} \mathrm{Cl}$ and $100 \mu \mathrm{M} \mathrm{Na}^{14} \mathrm{NO}_{2}^{-}$tracer in anaerobic slurries indicated anammox activity. Nitrification can lead to artifacts when using a ${ }^{15} \mathrm{NH}_{4}^{+}$tracer, but the absence of ${ }^{30} \mathrm{~N}_{2}$ production indicated that the slurries were sufficiently anaerobic to preclude nitrification. The rate of $\mathrm{N}_{2}$ production by anammox was determined from the regression of ${ }^{29} \mathrm{~N}_{2}$ production against time, which was then corrected for the fraction of ${ }^{15} \mathrm{~N}$-labeled $\mathrm{NH}_{4}^{+}$according to Holtappels (2011)

The optimum temperature $\left(T_{\mathrm{opt}}\right)$ was visually determined from plots of rates against temperature. Additionally, a range for $T_{\mathrm{opt}}$ was defined where rates did not fall below $90 \%$ of the optimum rate. The slope of temperature response was modeled using the Arrhenius function. A regression through the linear range of the plot of inverse temperature against the natural log of denitrification (or anammox) rate provided an estimate of activation energy according the equation

$\ln (k)=\ln (A)+\left(\frac{-E_{\mathrm{a}}}{R T}\right)$,

where $k$ is the reaction rate, and $T_{\mathrm{opt}}$ is the activation energy $\left(\mathrm{kJ} \mathrm{mol}^{-1}\right)$. In addition to the activation energy, the ratio of the potential rate at $5^{\circ} \mathrm{C}$ to the rate at in situ temperature was calculated as an indicator of psychrophilic adaptation.

\subsection{Analytical procedures}

Dissolved nitrate + nitrite $\left(\mathrm{NO}_{\mathrm{x}}^{-}\right)$and nitrite $\left(\mathrm{NO}_{2}^{-}\right)$were determined by chemiluminescence detection after reduction to $\mathrm{NO}$ gas on a Thermo model $42 \mathrm{i} \mathrm{NO}$ analyzer (Thermo Scientific). Nitrate + nitrite were reduced with an acidic $\mathrm{VCl}_{3}$ solution (Braman and Hendrix, 1989), and nitrite was reduced using an acidic iodide solution (Garside, 1982). Dissolved ammonium $\left(\mathrm{NH}_{4}^{+}\right)$was determined by the colorimetric method of Bower and Holm-Hansen (Bower and HolmHansen, 1980). Concentrations of ${ }^{29} \mathrm{~N}_{2}$ and ${ }^{30} \mathrm{~N}_{2}$ in excess of natural abundance were measured by either isotope ratio mass spectrometry (IRMS) (Sylt) or membrane-inlet mass spectrometry (St. George and Ymerbukta). For IRMS, a gas sample from the helium-equilibrated $(2 \mathrm{~mL})$ headspace of each Exetainer ${ }^{\circledR}$ was analyzed. The membrane inlet mass spectrometer was configured and calibrated according to An et al. (2001). An air-equilibrated standard of $0.2 \mu \mathrm{m}$ filtered site water or seawater was maintained at in situ temperature in a thermostatic water bath and was analyzed every $20 \mathrm{~min}$ to correct for instrument drift. Oxygen was removed from the vacuum system inlet before entering the mass spectrometer using a heated $\left(600^{\circ} \mathrm{C}\right)$ quartz column with copper turnings.

\section{Results}

Sediment characteristics for each site are shown in Table 1. Sediments were comprised of fine-to-medium grained sands, except at the polar site, which contained a mix of sand and very fine gravel (Table 1). The median grain size was 211 $223 \mu \mathrm{m}$ at the subtropical sites and 338 and $824 \mu \mathrm{m}$ at the temperate and polar sites, respectively. Permeabilities ranged from $1.0 \times 10^{-10}$ to $4.8 \times 10^{-11} \mathrm{~m}^{2}$ and were sufficiently high to permit advective pore-water exchange (Huettel and Rusch, 2000). The organic carbon contents were $<0.1 \%$ at the subtropical and temperate sites, and $\mathrm{C}: \mathrm{N}$ ratios for these sites were between 7.1 and 8.4. The polar site had an organic carbon content of $0.49 \%$ and a $\mathrm{C}: \mathrm{N}$ ratio of 22.6 .

\subsection{Rates and pathways of $\mathrm{N}_{2}$ production}

The isotope pairing technique, modified according to Risgaard-Petersen et al. (2003), was used to estimate the rate of unlabeled $\mathrm{N}_{2}$ production, p14, in intact $3.5 \mathrm{~cm}$ diameter cores. Areal rates of p14 varied between 1.9 and $359 \mu \mathrm{mol} \mathrm{m}^{-2} \mathrm{~d}^{-1}$ (Table 2). Simulated pore-water advection by perfusion led to substantial increases in $\mathrm{N}_{2}$ production rates at all sites. An approximately 2-fold increase in p14 was observed upon perfusion of the subtropical sediments. Perfusion led to a larger increase of p14 in the winter temperate and polar (5-fold) and summer temperate (7-fold) sediments. The highest denitrification rate $\left(359 \mu \mathrm{mol} \mathrm{m}^{-2} \mathrm{~d}^{-1}\right)$ was observed with sediment perfusion at the temperate site. For all sites, denitrification was the dominant pathway for $\mathrm{N}_{2}$ production. At Sylt, the contribution of anammox to $\mathrm{N}_{2}$ production was $14 \%$ in winter and $6 \%$ in summer, and anammox was responsible for $6.5 \%$ of $\mathrm{N}_{2}$ production at Ymerbukta. The contribution of anammox was below the detection limit in sediments from St. George Island.

\subsection{Vertical profiles of denitrification and anammox}

Pore-water DIN profiles and potential rates of denitrification and anammox at Sylt (June) revealed a vertical structure of N-removal mechanisms within the sediment (Fig. 2). Pore-water DIN profiles showed elevated ammonium and nitrate concentrations below $4 \mathrm{~cm}$. Concentrations were constant from 4 to $10 \mathrm{~cm}$, and were approximately $12 \mu \mathrm{M}$ for both nitrate and ammonium. Potential denitrification rates exhibited a maximum of $120 \mu \mathrm{mol} \mathrm{L}^{-1} \mathrm{~d}^{-1}$ between 2 and $6 \mathrm{~cm}$, whereas, anammox gradually increased with depth to a maximum rate of $20 \mu \mathrm{mol} \mathrm{L} \mathrm{L}^{-1} \mathrm{~d}^{-1}$ at $8-10 \mathrm{~cm}$. The anammox trend with depth was confirmed in parallel incubations with ${ }^{15} \mathrm{NH}_{4}^{+}$tracer additions (data not shown).

\subsection{Temperature response of denitrification and anammox}

Potential rates of denitrification and anammox were determined between $-1{ }^{\circ} \mathrm{C}$ and $42^{\circ} \mathrm{C}$ in a temperature gradient 
Table 2. Isotope pairing technique (IPT) rate measurements of denitrification and anammox. The production of unlabeled $\mathrm{N}_{2}$ (p14) was calculated according to Risgaard-Petersen et al. (2004), and the contribution of anammox (\% Anammox) was determined in anaerobic slurries according to Thamdrup and Dalsgaard (2002). Error estimates for p14 were determined from the standard error of the regression slope.

\begin{tabular}{llrrrrr}
\hline Site & Date & $\begin{array}{r}\text { Sediment } \\
T\left({ }^{\circ} \mathrm{C}\right)\end{array}$ & $\begin{array}{r}\text { Bottom } \\
\text { Water } \\
\mathrm{NO}_{3}^{-}(\mu \mathrm{M})\end{array}$ & $\begin{array}{r}\text { Diffusive } \\
\text { Conditions }\end{array}$ & $\begin{array}{r}\text { Simulated } \\
\text { Advection }\end{array}$ & $\begin{array}{r}\text { Anammox } \\
\%\end{array}$ \\
\hline SGI Gulf (Gulf of Mexico) & June 2011 & 29.9 & 1.7 & $8.8 \pm 1.1$ & $15 \pm 3.7$ & $0 \%$ \\
SGI Bay (Gulf of Mexico) & June 2011 & 31.8 & 2.2 & $1.9 \pm 0.6$ & $3.4 \pm 0.7$ & $0 \%$ \\
Sylt (Wadden Sea) & March 2007 & 5.3 & 53.9 & $79.7 \pm 2.7$ & $359 \pm 75$ & $14.0 \%$ \\
Sylt (Wadden Sea) & June 2007 & 19 & 0.8 & $6.5 \pm 1.7$ & $47.6 \pm 29.6$ & $6.0 \%$ \\
Ymerbukta (Svalbard) & August 2010 & 6.8 & 0.5 & $9.9 \pm 2.8$ & $49 \pm 6.8$ & $6.5 \%$ \\
\hline
\end{tabular}
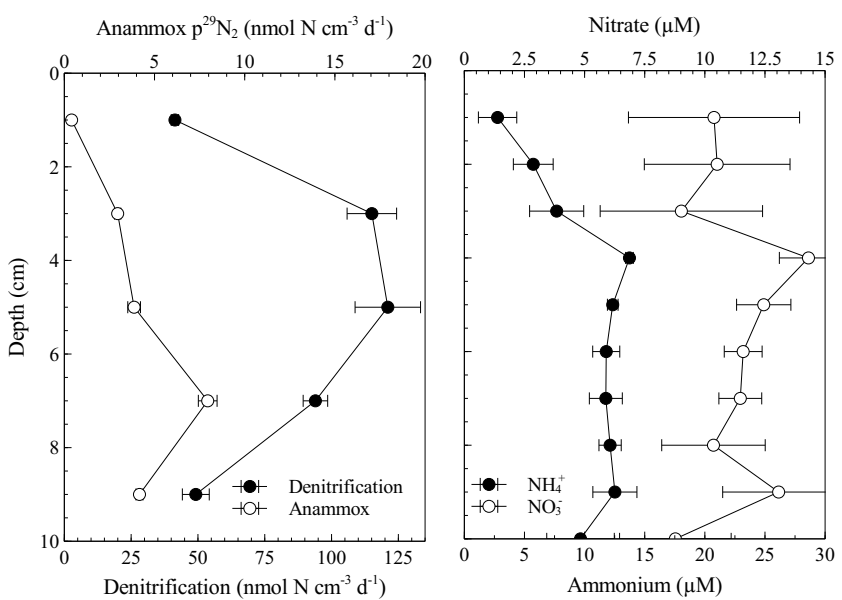

Fig. 2. Left: depth resolved potential rates of denitrification and anammox from Sylt in June 2007. Experiments using ${ }^{15} \mathrm{NO}_{3}^{-}$and ${ }^{15} \mathrm{NH}_{4}^{+}$tracers were used to estimate denitrification and anammox, respectively. Right: pore water profiles of nitrate and ammonium from Sylt in June 2007. Error bars represent the standard error of 3 replicate profiles.

block incubator. The optimum temperature for denitrification $\left(T_{\mathrm{opt}}\right)$ varied with the in situ temperature, with a $T_{\mathrm{opt}}$ of $21^{\circ} \mathrm{C}$ observed at the polar site and $35-36^{\circ} \mathrm{C}$ observed at the subtropical sites, respectively (Fig. 3). The temperate site exhibited a seasonal pattern in the $T_{\text {opt }}$ of denitrification, with a $T_{\text {opt }}$ of $26^{\circ} \mathrm{C}$ observed in the winter and $34^{\circ} \mathrm{C}$ observed in the summer. Both the temperate and polar site had broad $T_{\mathrm{opt}}$ peaks with widths of $7-9^{\circ} \mathrm{C}$ (Table 3), whereas the subtropical site had well-defined, narrow peaks $\left(2^{\circ} \mathrm{C}\right.$ or less).

At the polar site, a relatively high rate of denitrification was observed at $5^{\circ} \mathrm{C}$, corresponding to $34 \%$ of $T_{\text {opt }}$; in contrast, rates at $5{ }^{\circ} \mathrm{C}$ comprised only $1 \%$ of the $T_{\text {opt }}$ rate at the subtropical site (Table 3). The ratio of rates at $5{ }^{\circ} \mathrm{C}$ relative to the $T_{\mathrm{opt}}$ at the temperate site was similar during both summer and winter field samplings (11-17\%). Activation energies $\left(E_{\mathrm{a}}\right)$ calculated from Arrhenius plots also indicated latitudinal variation in the temperature response of denitrification
(Table 3). The $E_{\mathrm{a}}$ values at the temperate and polar sites were similar at $52-65 \mathrm{~kJ} \mathrm{~mol}^{-1}$. In contrast, the activation energies for denitrification at the subtropical site ranged from 102.7 to $123.5 \mathrm{~kJ} \mathrm{~mol}^{-1}$, corresponding to a 1.5-2-fold higher activation energy than at the temperate and polar sites (Table 3, Supplementary material). Normalization of the temperature response curves to the denitrification rate at $T_{\mathrm{opt}}$ revealed two trends: $T_{\text {opt }}$ increased with increasing environmental temperature, and temperate and polar sediments had higher relative rates at low temperatures as compared to subtropical sediments (Fig. 5).

The temperature response of anammox was only determined for Sylt and Ymerbukta, as anammox could not be detected at the subtropical SGI sites. Rates from the temperature gradient block experiments using ${ }^{15} \mathrm{NH}_{4}^{+}$tracer additions are reported here rather than rates determined using a ${ }^{15} \mathrm{NO}_{3}^{-}$tracer. Because denitrification rates were at least an order of magnitude higher than anammox rates in temperature block experiments, underestimation of the denitrification rate (estimated by production of ${ }^{30} \mathrm{~N}_{2}$ ) could produce a false anammox signal in experiments with ${ }^{15} \mathrm{NO}_{3}^{-}$tracer. The use of ${ }^{15} \mathrm{NH}_{4}^{+}$tracer is generally accepted as providing more conclusive evidence of anammox activity (Holtappels et al., 2011), and thus, these experiments were chosen as the best approach for estimating the anammox temperature response. Temperature optima of 9 and $26^{\circ} \mathrm{C}$ were observed for anammox at the polar and temperate sites, respectively (Fig. 4). For both sites, anammox rates at $5{ }^{\circ} \mathrm{C}$ comprised $35 \%$ of the $T_{\mathrm{opt}}$ rate. The activation energy for anammox was $35 \mathrm{~kJ} \mathrm{~mol}^{-1}$ at the temperate site (Table 3), but activation energy could not be accurately calculated from the temperature response curve at the polar site. Normalization of the temperature response curves to the anammox rate at $T_{\mathrm{opt}}$ clearly shows a higher $T_{\mathrm{opt}}$ at the temperate site versus the polar site, but similar relative rates at lower temperatures are observed (Fig. 5). 

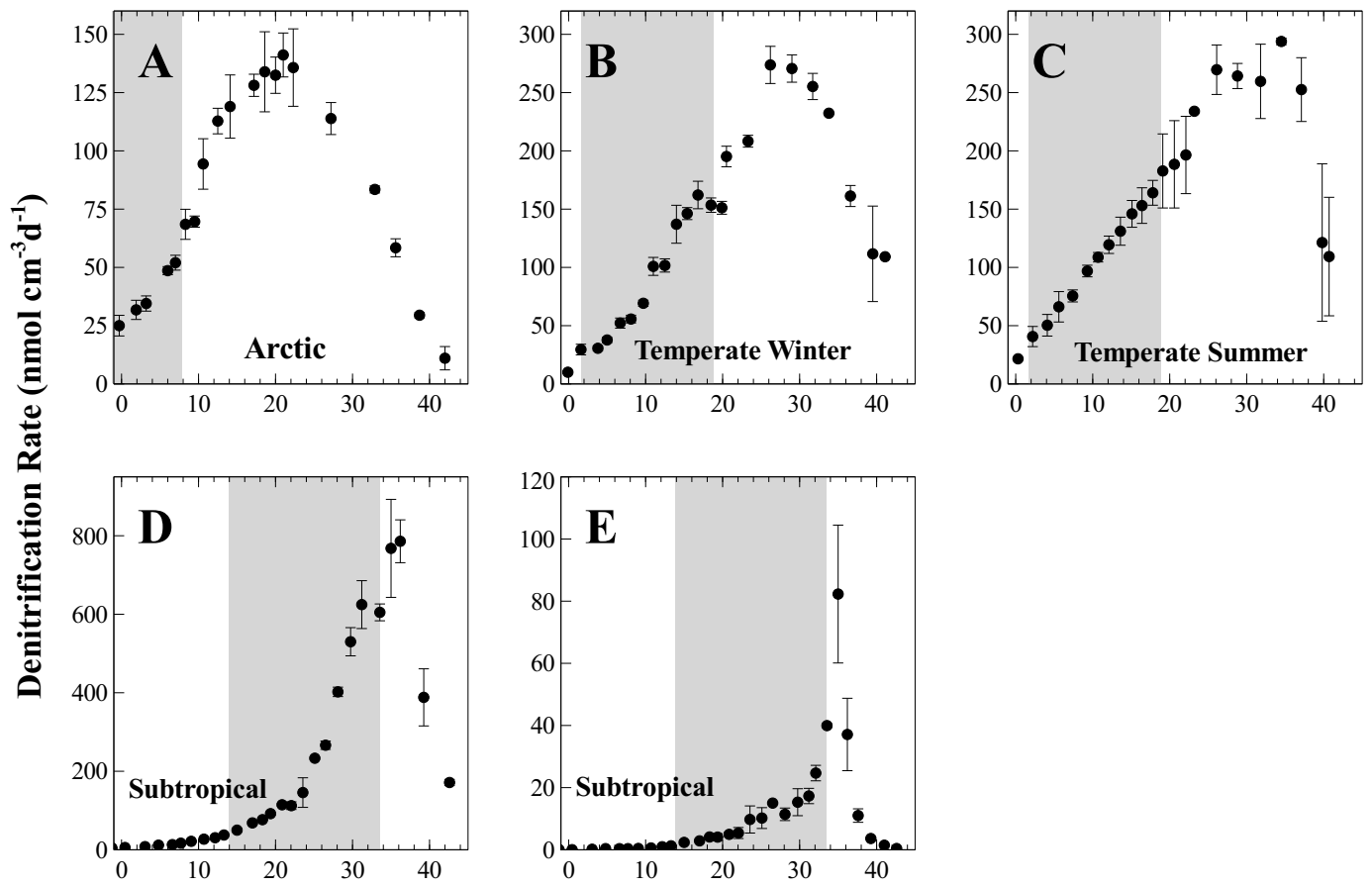

Temperature $\left({ }^{\circ} \mathrm{C}\right)$

Fig. 3. Potential denitrification rates measured in temperature gradient block experiments for (A) Ymerbukta, (B) Sylt (March 2007), (C) Sylt (June 2007), (D) SGI Gulf, and (E) SGI Bay. The seasonal temperature range is indicated by gray rectangles (note that the seasonal minimum for panel $\mathrm{A}$ is $-20^{\circ} \mathrm{C}$ ). Error bars represent the standard error of the regression slope calculated at each temperature. Note different $y$ axis scaling.

Table 3. Optimum temperatures $\left(T_{\mathrm{opt}}\right)$, apparent activation energy $\left(E_{\mathrm{a}}\right)$, and ratio of rates at $5^{\circ} \mathrm{C}$ relative to $T_{\mathrm{opt}}$ for anammox and denitrification in permeable sediments. The range of the $T_{\text {opt }}$ peak where rates did not fall below $90 \%$ of the optimum rate is noted in parentheses. Values of $Q_{10}$ were calculated between $T_{\mathrm{opt}}$ and $T_{\mathrm{opt}}-10^{\circ} \mathrm{C}$.

\begin{tabular}{llrrrrr}
\hline & & SGI Gulf & SGI Bay & Sylt Summer & Sylt Winter & Ymerbukta \\
\hline \multirow{2}{*}{ Denitrification } & $E_{\mathrm{a}}\left({ }^{\circ} \mathrm{C}\right)$ & $36(35-37)$ & 35 & $34(26-35)$ & $26(24-32)$ & $21(17-24)$ \\
& Rate at $5{ }^{\circ} \mathrm{C}$ relative to $T_{\mathrm{opt}}$ & $1.4 \%$ & $0.4 \%$ & $17.1 \%$ & $11.2 \%$ & $34.4 \%$ \\
& $E_{\mathrm{a}}\left(\mathrm{kJ} \mathrm{mol}^{-1}\right)$ & $102.7 \pm 2.1$ & $123.5 \pm 4.0$ & $51.7 \pm 3.8$ & $65.0 \pm 4.0$ & $57.8 \pm 4.4$ \\
& $Q_{10}$ & 3.8 & 5.0 & 2.0 & 2.5 & 2.3 \\
\hline \multirow{2}{*}{ Anammox } & $E_{\mathrm{a}}\left({ }^{\circ} \mathrm{C}\right)$ & N.A. & N.A. & $26(22-29)$ & N.D. & 9 \\
& Rate at $5{ }^{\circ} \mathrm{C}_{\text {relative }} T_{\mathrm{opt}}$ & N.A. & N.A. & $34.8 \%$ & N.D. & $35 \%$ \\
& $T_{\mathrm{opt}}\left(\mathrm{kJ} \mathrm{mol}^{-1}\right)$ & N.A. & N.A. & $35.0 \pm 4.9$ & N.D. & N.D. \\
& $Q_{10}$ & N.A. & N.A. & 1.6 & N.D. & N.D.
\end{tabular}

N.A., no detectable activity; N.D., not determined.

\section{Discussion}

\subsection{Controls of $\mathrm{N}$ removal in permeable sediments}

The controls of N removal at the temperate site at Sylt were the most extensively investigated based on previous results, indicating high rates of $\mathrm{N}$ removal. The Sylt-Romo basin receives nitrate from the Elbe and Weser rivers, with nitrate concentrations in the List tidal basin ranging from up to $60 \mu \mathrm{M}$ in winter to less than $1 \mu \mathrm{M}$ in summer (van Beusekom et al., 2008). In a recent study of sediment nitrogen dynamics in the same area, $\mathrm{N}_{2}$ effluxes measured under diffusive conditions ranged from 144 to $1128 \mu \mathrm{mol} \mathrm{N} \mathrm{m}^{-2} \mathrm{~d}^{-1}$ in February and April but $\mathrm{N}_{2}$ production was not detected in summer when water column nitrate concentrations were low (Deek et al., 2012). In the present study, intact core incubations 


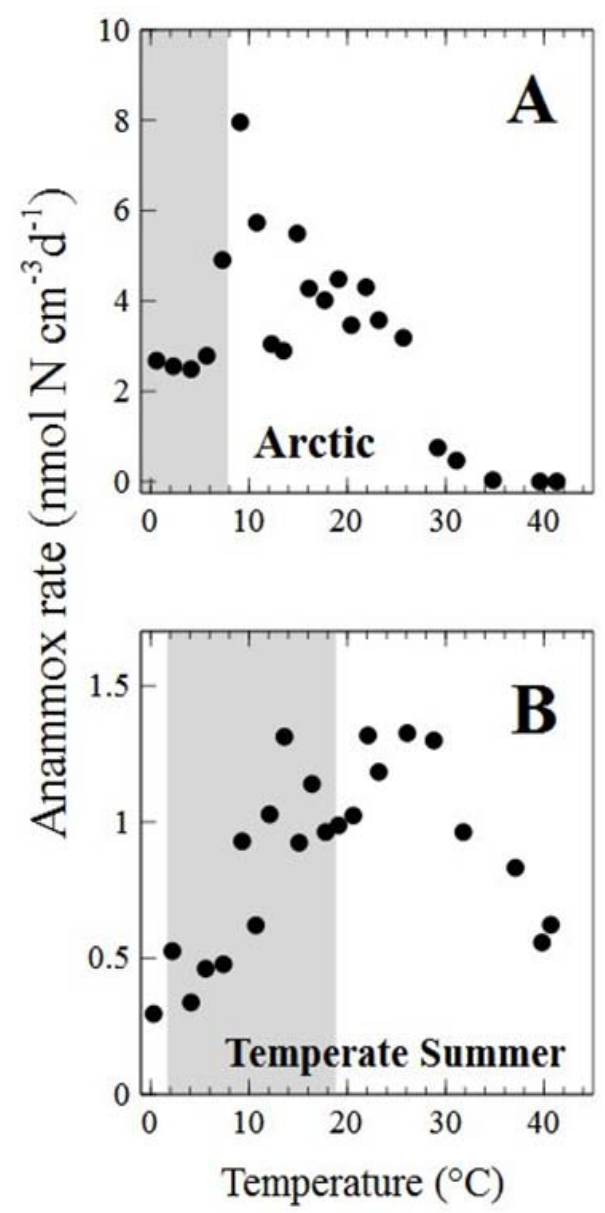

Fig. 4. Potential anammox rates measured in temperature gradient block experiments for (A) Ymerbukta and (B) Sylt (June 2007). Rates were measured with a ${ }^{15} \mathrm{NH}_{4}^{+}$label. Estimates of standard error were not made because rates were calculated from two time points. Note different $y$ axis scaling.

showed higher rates of $\mathrm{N}_{2}$ production in March relative to June under both diffusive and simulated pore-water advective conditions. These results indicate that seasonal variation in nitrogen loading is likely the dominant driver of the seasonal variability in $\mathrm{N}$ removal. The production of $\mathrm{N}_{2}$ in winter months at Sylt is likely sustained by the advective transport of nitrate-rich water into the denitrification zone, whereas in summer, nitrate must be supplied from within the sediment. In June, pore-water profiles showed that $10-12 \mu \mathrm{M}$ nitrate was present in the upper $10 \mathrm{~cm}$ of sediment, despite being nearly absent in the overlying water. This nitrate is likely supplied via nitrification, enhanced by bioturbation and bioirrigation of macrofauna (Huettel, 1990), as well as groundwater sources that have been shown to locally contribute inorganic nitrogen to the pore water at Sylt (Hedtkamp, 2005). Rates of anammox were approximately $10 \%$ or less of denitrification, which agrees well with measurements in similar temperate sediments (Evrard et al., 2013).
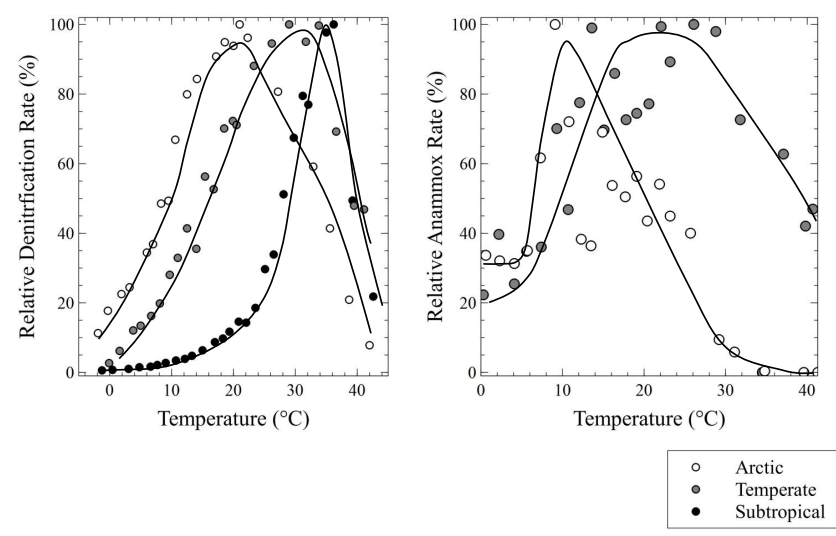

Fig. 5. Left: normalized temperature response of denitrification for subtropical, temperate, and Arctic sites. Right: normalized temperature response of anammox for temperate and Arctic sites. Curves were visually fit and error bars are omitted for clarity.

The rates from the present study add to a limited number of observations of $\mathrm{N}_{2}$ production in advection-dominated permeable sediments. For sites with low bottom water nitrate $(<5 \mu \mathrm{M})$, previous isotope pairing technique incubations in sandy sediments under diffusive conditions have measured rates of denitrification between 34 and $108 \mu \mathrm{mol} \mathrm{N} \mathrm{m}{ }^{-2} \mathrm{~d}^{-1}$ (Deutsch et al., 2010; Gihring et al., 2010; Lohse et al., 1996; Vance-Harris and Ingall, 2005). Simulated advection in a subset of these studies has produced rates of denitrification between 99 and $480 \mu \mathrm{mol} \mathrm{N} \mathrm{m}{ }^{-2} \mathrm{~d}^{-1}$ (Cook et al., 2007; Gihring et al., 2010). In contrast to sites with low bottom water nitrate, rates from two distinct sites in the Wadden Sea with seasonally high water column nitrate (40$85 \mu \mathrm{M})$ were between $450-1128 \mu \mathrm{mol} \mathrm{N} \mathrm{m}^{-2} \mathrm{~d}^{-1}$ under diffusive conditions, and substantially higher rates were observed (4000-25000 $\mu \mathrm{mol} \mathrm{N} \mathrm{m}{ }^{-2} \mathrm{~d}^{-1}$ ) with simulated pore water advection (Deek et al., 2012; Gao et al., 2012). Rates of sediment-water $\mathrm{N}_{2}$ flux under continuous advective conditions are generally higher than the rates obtained by IPT (480-1680 $\mu \mathrm{mol} \mathrm{N} \mathrm{m}{ }^{-2} \mathrm{~d}^{-1}$; Kessler et al. (2012) and references therein), indicating that the simulated pore water advection technique may underestimate $\mathrm{N}_{2}$ removal rates from permeable sediments. It has yet to be demonstrated whether the rates observed using IPT at sites with high bottom water nitrate concentrations are higher under continuous advection.

Microbial community structure has an important role in determining $\mathrm{N}_{2}$ removal under the dynamic redox conditions experienced in permeable sediments. A recent investigation of the kinetics of denitrification in permeable sediments found that the efficiency of denitrification (as indicated by the ratio of $\mathrm{O}_{2}$ consumption to maximum denitrification rate) was much lower than the stoichiometric ratio of 0.8 expected for denitrification (Evrard et al., 2013). It was postulated that the microbial community was likely not able to immediately shift from oxygen to nitrate respiration, 
and thus, the rate of carbon metabolism was temporarily reduced. It follows that under low bottom water nitrate concentrations, dynamic topography and variation in flushing create a limited and shifting denitrification zone, which may preclude the establishment of a robust community of facultative anaerobes capable of denitrification. However, at sites with a higher concentration of bottom water (and pore water) nitrate (e.g., Sylt), it is likely that the community of denitrifying facultative anaerobes will be well established, and the kinetics of nitrate reduction at these sites may allow for rapid rates of $\mathrm{N}$ removal, possibly under aerobic conditions (Gao et al., 2010). More measurements of kinetics and community structure are needed to adequately examine this hypothesis.

\subsection{Temperature adaptation of denitrification}

The adaptation of denitrifying microbial communities to in situ temperatures was inferred from multiple parameters of the temperature response curves, including the temperature optima $\left(T_{\mathrm{opt}}\right)$, activation energies $\left(E_{a}\right)$, and the ratio of denitrification at $5{ }^{\circ} \mathrm{C}$ to $T_{\mathrm{opt}}$, all of which varied directly with in situ temperatures. It is important to note that the $T_{\mathrm{opt}}$ of growth rates are used to define psychrophiles and mesophiles according to the classification scheme of Morita (1975), but $T_{\mathrm{opt}}$ for respiration rates were measured in the present study. Temperature gradient block incubations were carried out over short $(<24 \mathrm{~h})$ timescales, and $T_{\text {opt }}$ values most likely reflect the optimal respiratory enzyme activity of the in situ microbial community, which may deviate from the $T_{\mathrm{opt}}$ for growth.

The $T_{\text {opt }}$ for denitrification fell into two ranges: a $T_{\text {opt }}$ of approximately $20-25^{\circ} \mathrm{C}$ for polar and winter temperate sites (Sylt winter) and a $T_{\mathrm{opt}}$ of approximately $35^{\circ} \mathrm{C}$ for subtropical and summertime temperate sites (Sylt summer). All $T_{\mathrm{opt}}$ values were greater than the in situ sediment temperature, although the subtropical sites had the smallest difference between $T_{\mathrm{opt}}$ and the in situ temperature, suggesting that these communities may be closer to their maximum efficiency at in situ temperatures than are the polar and cold temperate communities. However, many purified psychrophilic enzymes have optimal catalytic rates between 15 and $30^{\circ} \mathrm{C}$, and the primary adaptation in psychrophilic enzymes is the maintenance of relatively high specific catalytic rates at low temperature (Feller and Gerday, 2003). The $T_{\mathrm{opt}}$ values for permeable sediments examined in this study are consistent with previous results from cold Arctic muds, where $T_{\mathrm{opt}}$ values of $20-28^{\circ} \mathrm{C}$ have been observed for aerobic respiration, denitrification, and sulfate reduction (Arnosti et al., 1998; Rysgaard et al., 2004). The community at the polar site (where $T_{\text {opt }}$ was lowest at $21^{\circ} \mathrm{C}$ ) may still be psychrophilic based on $T_{\mathrm{opt}}$ values for growth, as denitrifying isolates obtained from this site had optimal growth rates between 5 and $15{ }^{\circ} \mathrm{C}$ (Canion et al., 2013). Similar results from pure cultures of psychrophilic sulfate-reducing bacteria corroborate our observations: values of $T_{\mathrm{opt}}$ for growth were found to be up to $10^{\circ} \mathrm{C}$ lower than those for sulfate respiration (Isaksen and Jorgensen, 1996). Results indicate that the properties of respiratory enzymes may be important in determining the $T_{\mathrm{opt}}$ for growth of mesophiles, whereas metabolic pathways other than respiration limit the $T_{\mathrm{opt}}$ for growth in psychrophiles.

Activation energy $\left(E_{\mathrm{a}}\right)$ can also be used as an indicator of adaptation to low temperatures in conjunction with the $T_{\mathrm{opt}}$ for denitrification. The $E_{\mathrm{a}}$ values for the denitrification temperature response integrate multiple enzymatic reactions of denitrifiers with a range of thermal adaptation, although lower values of $E_{\text {a }}$ generally indicate high relative rates at low temperatures as a result of psychrophilic adaptation. Subtropical sediments had $E_{\mathrm{a}}$ values of 102 $123 \mathrm{~kJ} \mathrm{~mol}^{-1}$, approximately twice that of the polar and temperate sites, which is interpreted as the presence of an exclusively mesophilic community. In contrast, the lower $E_{\text {a }}$ values at the polar and temperate sites were indicative of a significant contribution of psychrophilic to psychrotolerant populations. The range of $E_{\mathrm{a}}$ we observed for polar and temperate sites $\left(50-65 \mathrm{~kJ} \mathrm{~mol}^{-1}\right)$ is comparable to previous observations of $E_{\mathrm{a}}$ of $60.6 \mathrm{~kJ} \mathrm{~mol}^{-1}$ for denitrification in Arctic marine muds (Rysgaard et al., 2004). The ratio of denitrification at $5{ }^{\circ} \mathrm{C}$ to $T_{\text {opt }}$ also confirms an increasing contribution of psychrophilic communities to denitrification across the gradient from subtropical to polar sediments. Specifically, polar sites exhibited rates of denitrification at $5{ }^{\circ} \mathrm{C}$ that were $34 \%$ of the rate at $T_{\mathrm{opt}}$, whereas the temperate and subtropical sites had rates at $5{ }^{\circ} \mathrm{C}$ that were 14 and $1 \%$ of $T_{\text {opt }}$, respectively.

Seasonal variation in $T_{\mathrm{opt}}$ was observed at the temperate site, Sylt, and the broadening of the $T_{\mathrm{opt}}$ in summer, rather than a clear shift towards a higher $T_{\text {opt }}$, suggests that psychrophilic to psychrotolerant denitrifying communities remain active in the summer when mesophilic activity is also apparent. Similarly, the $E_{\mathrm{a}}$ for denitrification at Sylt was similar between summer and winter months, indicating that psychrophilic/psychrotolerant populations still contributed to denitrification in the summer. Seasonal variation in $T_{\text {opt }}$ for nitrate reduction has been observed in temperate salt-marsh sediments, where two distinct temperature optima for nitrate reduction at 12.8 and $28^{\circ} \mathrm{C}$ were observed in winter and spring, respectively (King and Nedwell, 1984). These two temperature optima were interpreted as evidence of two nitrate-reducing communities with distinct temperature adaptation. In the present study, such a low temperature optimum in the winter was not observed; however, the $T_{\mathrm{opt}}$ of $12.8^{\circ} \mathrm{C}$ in the study of King and Nedwell (1984) may have been the result of a seasonal development of an anammox community (see below), but the study was conducted prior to the discovery of anammox.

\subsection{Temperature adaptation of anammox}

Multiple lines of evidence in this study indicate that the anammox process is well-adapted to cold conditions. At both the polar and temperate sites, low $T_{\mathrm{opt}}$ and $E_{\mathrm{a}}$ values 
of anammox relative to denitrification and the ratio of the anammox rate at $5{ }^{\circ} \mathrm{C}$ to $T_{\text {opt }}(35 \%)$ all support cold adaptation. Anammox activity was also absent from the subtropical sites. A $T_{\mathrm{opt}}$ of $9^{\circ} \mathrm{C}$ at the polar site is consistent with the optima of $12-15^{\circ} \mathrm{C}$ previously observed in Arctic fjord and deep North Sea muds, with in situ temperatures of -1.3 and $6^{\circ} \mathrm{C}$, respectively (Dalsgaard and Thamdrup, 2002; Rysgaard et al., 2004). Nitrification, which supplies nitrite for the anammox reaction, was found to have $T_{\mathrm{opt}}$ values of 8 $16^{\circ} \mathrm{C}$ in Svalbard fjord muds, closely corresponding to the $T_{\mathrm{opt}}$ for anammox (Thamdrup and Fleischer, 1998). The $T_{\mathrm{opt}}$ of $26^{\circ} \mathrm{C}$ at the temperate site is similar to previously reported $T_{\text {opt }}$ values of approximately $25^{\circ} \mathrm{C}$ for enrichments of marine anammox bacteria performed at $15-30^{\circ} \mathrm{C}$ (Kawagoshi et al., 2012; van de Vossenberg et al., 2008). The temperate $T_{\text {opt }}$ of $26^{\circ} \mathrm{C}$ for anammox indicates a psychrotolerant rather than a mesophilic response (see the previous section for rationale). Based on previous observations of the $T_{\mathrm{opt}}$ for respiration and growth on sulfate in pure cultures of mesophiles (Isaksen and Jorgensen, 1996), a $T_{\mathrm{opt}}$ for anammox higher than $30^{\circ} \mathrm{C}$ would be expected if the anammox community at the temperate site were dominated by mesophiles.

Anammox bacteria detected in the marine environment belong almost exclusively to the genus Scalindua, within the Planctomycetes, and evidence for temperature-selected ecotypes has been found in enrichments from temperate fjord sediments (van de Vossenberg et al., 2008). However, reports of anammox activity in marine samples are generally limited to environmental temperatures of $25^{\circ} \mathrm{C}$ or less. The compilation of the marine anammox activity measurements in Schmid et al. (2007) includes oxygen minimum zone water columns, temperate sediments, and polar sediments with a range of in situ temperatures between -1.5 and $17^{\circ} \mathrm{C}$, with one observation at $20^{\circ} \mathrm{C}$. Anammox activity has been detected in temperate estuarine sediments with in situ temperatures ranging from $15-19^{\circ} \mathrm{C}$ (Dale et al., 2009; Teixeira et al., 2012), and rates were depressed or undetectable in summer months when temperatures were above $20^{\circ} \mathrm{C}$. The presence of anammox has been confirmed in subtropical and tropical mangrove sediments (Fernandes et al., 2012; Meyer et al., 2005); however, anammox communities in brackish mangrove sediments may be more metabolically diverse than those of marine sediments exposed to higher salinities (Amano et al., 2011). Along with the evidence from temperature block incubations in the present study, these studies suggest that marine anammox bacteria (Scalindua) are predominately psychrophilic to psychrotolerant. However, more surveys of the activity and diversity of anammox bacteria are required to thoroughly test this observation.

\section{Implications for $\mathrm{N}$ removal on continental shelves}

Rates of nitrogen removal from sands under simulated pore water advection in the present study corroborate previous re- sults that have shown permeable shelf sediments to be dynamic sites of $\mathrm{N}$ removal. Furthermore, shelf environments with consistently high concentrations of nitrate in bottom waters generally have higher rates of $\mathrm{N}$ removal, which may be related to microbial community structure. To our knowledge, we provide the first report of denitrification and anammox activity from permeable sediments of a polar or permanently cold ecosystem. The contribution of Arctic permeable shelf sediments to global $\mathrm{N}$ removal is likely significant, given the vast continental shelf of the Arctic Ocean.

Microbial community adaptation to in situ temperatures has been previously demonstrated in fine-grained marine sediments for aerobic respiration, hydrolysis, nitrate respiration, and sulfate reduction (Rysgaard et al., 2004; Arnosti et al., 1998; Thamdrup et al., 1998). In permeable continental shelf sediments, we observed a strong temperature adaptation of microbial communities that mediate denitrification to in situ temperature, and marine anammox bacteria appear to thrive in sediments exposed to colder conditions. Thus, other environmental parameters are likely to outweigh temperature as the dominant control on sediment $\mathrm{N}$ loss rates from permeable sediments.

\section{Supplementary material related to this article is available online at http://www.biogeosciences.net/11/309/ 2014/bg-11-309-2014-supplement.pdf.}

Acknowledgements. This study was supported by grants from the National Science Foundation (OCE-0424967 and OCE-0726754), Florida State University (PEG 513680014), and the Max Planck Society. A Canion received partial support from the BP Gulf of Mexico Research Initiative to the Deep-C Consortium. Partial support was provided to J. E. Kostka by the Hanse Wissenschaftskolleg. T. M. Gihring was supported in part by a fellowship from the Estuarine Reserves Division, National Oceanic and Atmospheric Administration. We thank P. Chanton, J. Kaba, and Y. Xu for their assistance with sample collection and analysis. We also acknowledge cruise participants and Captain S. Hennigsen for assistance with sample collection in Svalbard in 2010, and we thank the Florida Department of Environmental Protection for permission to sample at St. George Island State Park.

Edited by: G. Herndl

\section{References}

Amano, T., Yoshinaga, I., Yamagishi, T., Thuoc, C. V., Thu, P. T., Ueda, S., Kato, K., Sako, Y., and Suwa, Y.: Contribution of Anammox Bacteria to Benthic Nitrogen Cycling in a Mangrove Forest and Shrimp Ponds, Haiphong, Vietnam, Microbes Environ., 26, 1-6, 2011.

An, S. M., Gardner, W. S., and Kana, T.: Simultaneous measurement of denitrification and nitrogen fixation using isotope pairing with 
membrane inlet mass spectrometry analysis, Appl. Environ. Microbiol., 67, 1171-1178, 2001.

Arnosti, C., Jorgensen, B. B., Sagemann, J., and Thamdrup, B.: Temperature dependence of microbial degradation of organic matter in marine sediments: polysaccharide hydrolysis, oxygen consumption, and sulfate reduction, Mar. Ecol.-Prog. Ser., 165, 59-70, 1998.

Bower, C. E. and Holm-Hansen, T.: A Salicylate-Hypochlorite Method for Determining Ammonia in Seawater, Can. J. Fish. Aquat. Sci., 37, 794-798, 1980.

Braman, R. S. and Hendrix, S. A.: Nanogram Nitrite and Nitrate Determination in Environmental and Biological-Materials by Vanadium(Iii) Reduction with Chemi-Luminescence Detection, Anal. Chem., 61, 2715-2718, 1989.

Canion, A., Prakash, O., Green, S. J., Jahnke, L., Kuypers, M. M. M., and Kostka, J. E.: Isolation and physiological characterization of psychrophilic denitrifying bacteria from permanently cold Arctic fjord sediments (Svalbard, Norway), Environ. Microbiol., 15, 1606-1618, doi:10.1111/1462-2920.12110, 2013.

Cardenas, M. B., Cook, P. L. M., Jiang, H. S., and Traykovski, P.: Constraining denitrification in permeable wave-influenced marine sediment using linked hydrodynamic and biogeochemical modeling, Earth Planet. Sci. Lett., 275, 127-137, doi:10.1016/j.epsl.2008.08.016, 2008.

Chipman, L., Huettel, M., and Laschet, M.: Effect of benthicpelagic coupling on dissolved organic carbon concentrations in permeable sediments and water column in the northeastern Gulf of Mexico, Cont. Shelf Res., 45, 116-125, doi:10.1016/j.csr.2012.06.010, 2012.

Codispoti, L. A.: An oceanic fixed nitrogen sink exceeding $400 \mathrm{Tg} \mathrm{N}$ a-1 vs the concept of homeostasis in the fixed-nitrogen inventory, Biogeosciences, 4, 233-253, doi:10.5194/bg-4-2332007, 2007.

Cook, P. L. M., Wenzhofer, F., Rysgaard, S., Galaktionov, O. S., Meysman, F. J. R., Eyre, B. D., Cornwell, J., Huettel, M., and Glud, R. N.: Quantification of denitrification in permeable sediments: Insights from a two-dimensional simulation analysis and experimental data, Limnol. Oceanogr. Meth., 4, 294-307, 2006.

Cook, P. L. M., Wenzhofer, F., Glud, R. N., Janssen, F., and Huettel, M.: Benthic solute exchange and carbon mineralization in two shallow subtidal sandy sediments: Effect of advective pore-water exchange, Limnol. Oceanogr., 52, 1943-1963, 2007.

Cornwell, J. C., Kemp, W. M., and Kana, T. M.: Denitrification in coastal ecosystems: methods, environmental controls, and ecosystem level controls, a review, Aquat. Ecol., 33, 41-54, 1999.

Dale, O. R., Tobias, C. R., and Song, B.: Biogeographical distribution of diverse anaerobic ammonium oxidizing (anammox) bacteria in Cape Fear River Estuary, Environ. Microbiol., 11, 1194 1207, doi:10.1111/j.1462-2920.2008.01850.x, 2009.

Dalsgaard, T. and Thamdrup, B.: Factors controlling anaerobic ammonium oxidation with nitrite in marine sediments, Appl. Environ. Microbiol., 68, 3802-3808, doi:10.1128/aem.68.8.38023808.2002, 2002.

de Beer, D., Wenzhofer, F., Ferdelman, T. G., Boehme, S. E., Huettel, M., van Beusekom, J. E. E., Bottcher, M. E., Musat, N., and Dubilier, N.: Transport and mineralization rates in North Sea sandy intertidal sediments, Sylt-Romo Basin, Wadden Sea, Limnol. Oceanogr., 50, 113-127, 2005.
Deek, A., Emeis, K., and van Beusekom, J.: Nitrogen removal in coastal sediments of the German Wadden Sea, Biogeochemistry, 108, 467-483, doi:10.1007/s10533-011-9611-1, 2012.

Deutsch, B., Forster, S., Wilhelm, M., Dippner, J. W., and Voss, M.: Denitrification in sediments as a major nitrogen sink in the Baltic Sea: an extrapolation using sediment characteristics, Biogeosciences, 7, 3259-3271, doi:10.5194/bg-7-3259-2010, 2010.

Emery, K. O.: Relict sediments on continental shelves of the world, Am. Assoc. Petrol. Geo. Bull., 52, 445-464, 1968.

Evrard, V., Glud, R., and Cook, P. M.: The kinetics of denitrification in permeable sediments, Biogeochemistry, 113, 563-572, doi:10.1007/s10533-012-9789-x, 2013.

Feller, G. and Gerday, C.: Psychrophilic enzymes: Hot topics in cold adaptation, Nat. Rev. Microbiol., 1, 200-208, doi:10.1038/nrmicro773, 2003.

Fernandes, S. O., Michotey, V. D., Guasco, S., Bonin, P. C., and Loka Bharathi, P. A.: Denitrification prevails over anammox in tropical mangrove sediments (Goa, India), Mar. Environ. Res., 74, 9-19, doi:10.1016/j.marenvres.2011.11.008, 2012.

Forland, E. J. and Hanssen-Bauer, I.: Past and future climate variations in the Norwegian Arctic: overview and novel analyses, Polar Research, 22, 113-124, doi:10.1111/j.17518369.2003.tb00102.x, 2003.

Galloway, J. N., Dentener, F. J., Capone, D. G., Boyer, E. W., Howarth, R. W., Seitzinger, S. P., Asner, G. P., Cleveland, C. C., Green, P. A., Holland, E. A., Karl, D. M., Michaels, A. F., Porter, J. H., Townsend, A. R., and Vorosmarty, C. J.: Nitrogen cycles: past, present, and future, Biogeochemistry, 70, 153-226, 2004.

Gao, H., Schreiber, F., Collins, G., Jensen, M. M., Kostka, J. E. Lavik, G., de Beer, D., Zhou, H. Y., and Kuypers, M. M. M.: Aerobic denitrification in permeable Wadden Sea sediments, Isme J., 4, 417-426, doi:10.1038/ismej.2009.127, 2010.

Gao, H., Matyka, M., Liu, B., Khalili, A., Kostka, J. E., Collins, G., Jansen, S., Holtappels, M., Jensen, M. M., Badewien, T. H., Beck, M., Grunwald, M., de Beer, D., Lavik, G., and Kuypers, M. M. M.: Intensive and extensive nitrogen loss from intertidal permeable sediments of the Wadden Sea, Limnol. Oceanogr., 57, 185-198, doi:10.4319/lo.2012.57.1.0185, 2012.

Garside, C.: A chemiluminescent technique for the determination of nanomolar concentrations of nitrate and nitrite in sea-water Mar. Chem., 11, 159-167, doi:10.1016/0304-4203(82)90039-1, 1982.

Gihring, T. M., Canion, A., Riggs, A., Huettel, M., and Kostka, J. E. Denitrification in shallow, sublittoral Gulf of Mexico permeable sediments, Limnol. Oceanogr., 55, 43-54, 2010.

Hedtkamp, S. I. C.: Shallow subtidal sand: Permeability, nutrient dynamics, microphytobenthos, and organic matter, Ph. D., Christian-Albrechts-Universität zu Kiel, Kiel, 141 pp., 2005.

Holtappels, M., Lavik, G., Jensen, M. M., and Kuypers, M. M. M.: 15-N Labeling Experiments to Dissect the Contributions of Heterotrophic Denitrification and Anammox to Nitrogen Removal in the OMZ Waters of the Ocean, Methods in Enzymology, 486, 223-251, 2011.

Huettel, M.: Influence of the lugworm Arenicola marina on porewater nutrient profiles of sand flat sediments, Mar. Ecol. Prog. Ser., 62, 241-248, 1990.

Huettel, M. and Rusch, A.: Transport and degradation of phytoplankton in permeable sediment, Limnol. Oceanogr., 45, 534$549,2000$. 
Huettel, M., Berg, P., and Kostka, J. E.: Benthic Exchange and Biogeochemical Cycling in Permeable Sediments, Annual Review of Marine Science, 6, In Press, doi:10.1146/annurev-marine051413-012706, 2014.

Isaksen, M. F. and Jorgensen, B. B.: Adaptation of psychrophilic and psychrotrophic sulfate-reducing bacteria to permanently cold marine environments, Appl. Environ. Microbiol., 62, 408-414, 1996.

Kaplan, W. A., Teal, J. M., and Valiela, I.: Denitrification in saltmarsh sediments - Evidence for seasonal temperature selection among populations of denitrifiers, Microb. Ecol., 3, 193-204, 1977.

Kawagoshi, Y., Fujisaki, K., Tomoshige, Y., Yamashiro, K., and Qiao, Y. W.: Temperature effect on nitrogen removal performance and bacterial community in culture of marine anammox bacteria derived from sea-based waste disposal site, Journal of Bioscience and Bioengineering, 113, 515-520, doi:10.1016/j.jbiosc.2011.11.024, 2012.

Kessler, A. J., Glud, R. N., Cardenas, M. B., Larsen, M., Bourke, M. F., and Cook, P. L. M.: Quantifying denitrification in rippled permeable sands through combined flume experiments and modeling, Limnol. Oceanogr., 57, 1217-1232, doi:10.4319/lo.2012.57.4.1217, 2012.

King, D. and Nedwell, D. B.: Changes in the nitrate-reducing community of an anaerobic saltmarsh sediment in response to seasonal selection by temperature, J. Gen. Microbiol., 130, 29352941, 1984.

Lohse, L., Kloosterhuis, H. T., vanRaaphorst, W., and Helder, W.: Denitrification rates as measured by the isotope pairing method and by the acetylene inhibition technique in continental shelf sediments of the North Sea, Mar. Ecol.-Prog. Ser., 132, 169-179, doi:10.3354/meps 132169, 1996.

Meyer, R. L., Risgaard-Petersen, N., and Allen, D. E.: Correlation between Anammox Activity and Microscale Distribution of Nitrite in a Subtropical Mangrove Sediment, Appl. Environ. Microbiol., 71, 6142-6149, doi:10.1128/aem.71.10.6142-6149.2005, 2005.

Morita, R. Y.: Psychrophilic bacteria, Bacteriological Reviews, 39, 144-167, 1975.

National Data Buoy Center: http://www.ndbc.noaa.gov, last access: 16 May 2012.

Nielsen, L. P.: Denitrification in Sediment Determined from Nitrogen Isotope Pairing, FEMS Microbiol. Ecol., 86, 357-362, 1992.

Ogilvie, B. G., Rutter, M., and Nedwell, D. B.: Selection by temperature of nitrate-reducing bacteria from estuarine sediments: Species composition and competition for nitrate, FEMS Microbiol. Ecol., 23, 11-22, 1997.

Risgaard-Petersen, N., Nielsen, L. P., Rysgaard, S., Dalsgaard, T., and Meyer, R. L.: Application of the isotope pairing technique in sediments where anammox and denitrification coexist, Limnol. Oceanogr. Meth., 1, 63-73, 2003.
Rysgaard, S., Glud, R. N., Risgaard-Petersen, N., and Dalsgaard, T.: Denitrification and anammox activity in Arctic marine sediments, Limnol. Oceanogr., 49, 1493-1502, 2004.

Sagemann, J., Jorgensen, B. B., and Greeff, O.: Temperature dependence and rates of sulfate reduction in cold sediments of Svalbard, Arctic Ocean, Geomicrobiol. J., 15, 85-100, 1998.

Sawicka, J. E., Robador, A., Hubert, C., Jorgensen, B. B., and Bruchert, V.: Effects of freeze-thaw cycles on anaerobic microbial processes in an Arctic intertidal mud flat, Isme J., 4, 585594, doi:10.1038/ismej.2009.140, 2010.

Schmid, M. C., Risgaard-Petersen, N., van de Vossenberg, J., Kuypers, M. M. M., Lavik, G., Petersen, J., Hulth, S., Thamdrup, B., Canfield, D., Dalsgaard, T., Rysgaard, S., Sejr, M. K., Strous, M., den Camp, H., and Jetten, M. S. M.: Anaerobic ammoniumoxidizing bacteria in marine environments: widespread occurrence but low diversity, Environ. Microbiol., 9, 1476-1484, 2007.

Seeberg-Elverfeldt, J., Schluter, M., Feseker, T., and Kolling, M.: Rhizon sampling of porewaters near the sediment-water interface of aquatic systems, Limnol. Oceanogr. Meth., 3, 361-371, 2005.

Teixeira, C., Magalhaes, C., Joye, S. B., and Bordalo, A. A.: Potential rates and environmental controls of anaerobic ammonium oxidation in estuarine sediments, Aquat. Microb. Ecol., 66, 2332, doi:10.3354/ame01548, 2012.

Thamdrup, B. and Fleischer, S.: Temperature dependence of oxygen respiration, nitrogen mineralization, and nitrification in Arctic sediments, Aquat. Microb. Ecol., 15, 191-199, 1998.

Thamdrup, B., Hansen, J. W., and Jorgensen, B. B.: Temperature dependence of aerobic respiration in a coastal sediment, FEMS Microbiol. Ecol., 25, 189-200, 1998.

Thamdrup, B. and Dalsgaard, T.: Production of N-2 through anaerobic ammonium oxidation coupled to nitrate reduction in marine sediments, Appl. Environ. Microbiol., 68, 1312-1318, doi:10.1128/aem.68.3.1312-1318.2002, 2002.

Thamdrup, B. and Dalsgaard, T.: Nitrogen Cycling in Sediments, in: Microbial Ecology of the Oceans, 2 ed., edited by: Kirchman, D. L., John Wiley and Sons, Hoboken, New Jersey, 527-568, 2008.

van Beusekom, J. E. E., Weigelt-Krenz, S., and Martens, P.: Longterm variability of winter nitrate concentrations in the Northern Wadden Sea driven by freshwater discharge, decreasing riverine loads and denitrification, Helgol. Mar. Res., 62, 49-57, doi:10.1007/s10152-007-0092-5, 2008.

van de Vossenberg, J., Rattray, J. E., Geerts, W., Kartal, B., van Niftrik, L., van Donselaar, E. G., Damste, J. S. S., Strous, M., and Jetten, M. S. M.: Enrichment and characterization of marine anammox bacteria associated with global nitrogen gas production, Environ. Microbiol., 10, 3120-3129, 2008.

Vance-Harris, C. and Ingall, E.: Denitrification pathways and rates in the sandy sediments of the Georgia continental shelf, USA, Geochem. T., 6, 12-18, doi:10.1063/1.1858091, 2005. 